\title{
Erratum to: Slave prices and productivity at the Cape of Good Hope from 1700 to 1725: Did all settler farmers profit from the trade?
}

\author{
Sophia Du Plessis • Ada Jansen • Dieter von Fintel
}

Published online: 16 December 2014

(c) Springer-Verlag Berlin Heidelberg 2014

\section{Erratum to: Cliometrica \\ DOI 10.1007/s11698-014-0116-8}

The authors would like to change the title of the original publication as detailed below and add a footnote to the title.

Title: Slave prices and productivity at the Cape of Good Hope from 1700 to 1725: did all settler farmers profit from the trade?

Footnote: This paper was previously entitled "Slave prices and productivity at the Cape of Good Hope from 1700 to 1725: Did everyone win from the trade?" The authors hereby acknowledge that the previous title is insensitive towards the oppression of slaves who clearly did not win from the trade. We apologise unconditionally for this error and withdraw all versions of the paper that do not specify (as was our intention in writing this work), that this research questions whether all settler farmers profited from the slave trade.

The online version of the original article can be found under doi:10.1007/s11698-014-0116-8.

S. Du Plessis $(\varangle) \cdot$ A. Jansen · D. von Fintel

Department of Economics, Stellenbosch University, Stellenbosch, South Africa

e-mail: sophia@sun.ac.za

D. von Fintel

Institute for the Study of Labour (IZA), Bonn, Germany 